TARNOWSKIE STUDIA TEOLOGICZNE 36 (2017) NR 1, S. 59-81

http://dx.doi.org/10.15633/tst.2324

ks. Paweł Nowak ${ }^{1}$

HILDESHEIM

\title{
Pobożność maryjna św. Jadwigi Śląskiej na tle ówczesnej epoki
}

Czasy św. Jadwigi Śląskiej to okres w dziejach Kościoła, w którym część dogmatów nie była jeszcze ostatecznie określona. Z tego powodu istniała dość duża przestrzeń dla rozwoju różnorodnych duchowości, również tych maryjnych. Jednak podstawy kultu maryjnego zostały położone przez Sobór Efeski w 431 roku przez potwierdzenie dogmatu o Bożym macierzyństwie Maryi ${ }^{2}$. Wielokrotnie powtarzane nauczanie Kościoła z czasem było ubogacane przez kolejne wątki teologiczne.

W duchowości ludzi średniowiecza Maryja zajmowała szczególne miejsce. Jej kult był jednym z fundamentów życia duchowego współczesnych ludzi. Wielu świętych było szczególnymi jej czcicielami. Warto choćby wspomnieć św. Bernarda z Clairvaux (†547), który przeszedł do historii z zaszczytnym mianem Piewcy Maryi. Jego pobożność maryjna wywarła wielki wpływ na cały zakon cystersów ${ }^{3}$, a przez to również pośrednio na pobożność

\footnotetext{
1 Paweł Nowak - ksiądz katolicki diecezji tarnowskiej. Studia teologiczne odbył na Uniwersytecie Papieskim Jana Pawła II w Krakowie Wydział Teologiczny Sekcja w Tarnowie, które w 2010 roku zwieńczył obroną pracy magisterskiej pt. Spór o racje religii. Polemika P. Moskala $z$ poglądami J. M. Bocheńskiego. W latach 2011-2014 kontynuował studia w ramach Studium Licencjackiego na tymże wydziale i uzyskał stopień magistra licencjata. W roku 2016 rozpoczął studia doktoranckie na Wydziale Teologicznym Katolickiego Uniwersytetu Lubelskiego Jana Pawła II w Instytucie Liturgiki i Homiletyki.

${ }^{2}$ W sensie ścisłym kult należy się wyłącznie Bogu. Najbardziej poprawne jest mówienie o „czci” Maryi. W artykule oba terminy będą używane zamiennie, ale w znaczeniu poprawnym teologicznie. Por. M. Zachara, Maryja. Kult liturgiczny, w: Encyklopedia katolicka, t. 12, red. E. Ziemianin, Lublin 2008, kol. 33-37; M. Straszewicz, Maryja. Kult pozaliturgiczny, w: Encyklopedia katolicka, t. 12, kol. 37-39; Cz. S. Bartnik, Matka Boża, Lublin 2012, s. 219-220; Z. Janiec, Kult Maryi w Polsce na przestrzeni dziejów. Zarys problematyki, Sandomierz 2013, s. 7-8.

3 Zob. D. Tabor, Psatterz trzebnicki. Między egzegeza a duchowością, w: Cysterki $w$ dziejach i kulturze ziem polskich, dawnej Rzeczypospolitej i Europy Środkowej. Materiały z siódmej
} 
maryjną św. Jadwigi Śląskiej, która po śmierci męża przeniosła się do Trzebnicy i zamieszkała w domu obok opactwa cysterskiego. Uczestniczyła ona chętnie w życiu klasztornym, nigdy jednak nie złożyła ślubów zakonnych ${ }^{4}$.

Celem niniejszego artykułu jest zaprezentowanie czci, jaką św. Jadwiga Śląska otaczała Matkę Bożą. Przedstawiając powyższe zagadnienie, będziemy skupiali swoją uwagę na analizie teksu Legenda maior ${ }^{5}$.

\section{Kim była św. Jadwiga Śląska}

$\mathrm{Na}$ temat życia św. Jadwigi Śląskiej wiedzę czerpiemy przede wszystkim ze źródeł ${ }^{6}$, na których opierają się wszystkie późniejsze biografie świętej i publikacje jej poświęcone. Jadwiga Śląska, obok św. Wojciecha i św. Stanisława, jest pierwszą kanonizowaną postacią w naszym kraju. Należy zauważyć nadto, że jest to pierwsza kobieta wyniesiona na ołtarze w historii Polski.

Jadwiga pochodziła z rodu bawarskich hrabiów z Andechs ${ }^{8}$. Daty jej urodzin nie da się ściśle określić z powodu jej braku w materiale źródłowym.

Międzynarodowej Konferencji Cystersologów odbytej z okazji 8oo. rocznicy fundacji opactwa cysterek $w$ Trzebnicy; Trzebnica 18-21 września 2002 r., red. A. M. Wyrwa, A. Kiełbasa, J. Swastek, Poznań 2004, s. 118.

4 Zob. G. M. Baran, P. Nowak, Święta Jadwiga Śląska - patronka dębickiego grodu, Dębica 2015, s. 49; M. Borkowska, Duchowość polskich klasztorów żeńskich $w$ średniowieczu, „Saeculum Christianum" 3 (1996) nr 1, s. 113.

5 W niniejszym artykule będziemy odwoływać się jedynie do polskiego tłumaczenia tekstu, ponieważ tekst Legenda maior nie jest pierwszorzędnym przedmiotem analiz. Wydanie krytyczne Vita s. Hedwigis (legenda maior) znajduje się w: Monumenta Poloniae Historica. Pomniki dziejowe Polski, wyd. A. Semkowicz, t. 4, Lwów 1884, s. 510-633. Żywot ten został wydany w języku polskim w: Legenda świętej Jadwigi, przetł. A. Jochelson, M. W. Gogolewska, przyg. do druku J. Pater, Wrocław 1993.

6 Najstarszy żywot św. Jadwigi zawarty jest w tak zwanej Legenda maior de beata Hedwigi (zob. J. Pater, Wartość historyczna „Żywota większego świętej Jadwigi”). Jest on datowany na ok. 1300 rok. Źródłami, które nie zachowały się do naszych czasów, był życiorys świętej powstały w niespełna dwadzieścia lat po jej śmierci, którego autor pozostaje nieznany, i biogram Vita S. Hedwigis autorstwa cystersa lubiąskiego Engelberta. Por. G. M. Baran, P. Nowak, Święta Jadwiga Śląska - patronka dębickiego grodu, s. 23-27.

7 Por. R. Piasecki, Kazanie o św. Jadwidze, w: G. M. Baran, P. Nowak, Święta Jadwiga Śląska - patronka dębickiego grodu, s. 167.

8 Por. B. Zientara, Świetność i upadek możnego rodu, czyli dramatyczne dzieje książąt Meranii, „Mówią Wieki” 1973 nr 3, s. 5. 
Jedni określają ją na rok $1174^{9}$, inni natomiast na rok pomiędzy $1178-1180^{10}$. Nie jest też do końca pewne, czy Jadwiga przyszła na świat w Andechs. Jej ojcem był bardzo znaczący książę Bertold vi, a matką Agnieszka z możnego rodu Wettynów. Swoje dzieciństwo od piątego roku życia spędziła nad jeziorem Amer w Kitzingen koło Würzburga, w znanym klasztorze benedyktynek. Klasztor ten słynął wówczas jako miejsce wychowania dla dziewcząt. Tu otrzymała, jak na ówczesne czasy, staranne i wszechstronne wykształcenie $^{11}$ oraz została uformowana duchowo, co ma ważne znaczenie dla poruszanego w niniejszym artykule zagadnienia. Klasztor ten formował swoich wychowanków w duchu św. Benedykta z Nursji ${ }^{12}$.

Pobyt Jadwigi w klasztorze w Kitzingen trwał około siedmiu lat. Następnie w wieku 12 lat została wysłana do Wrocławia na dwór księcia śląskiego Bolesława Wysokiego i przeznaczona na żonę jego syna Henryka I, zwanego Brodatym, choć początkowo planowano dla niej małżeństwo z Toljenem Nemaniczem, synem serbskiego żupana ${ }^{13}$. Sama Jadwiga z pewnością chętniej poświęciłaby się życiu zakonnemu. Dowiadujemy się o tym z Legenda maior: „Samą zaś Jadwigę, służebnicę Pańską, w wieku lat 12 połączono węzłem małżeńskim z wielmożnym księciem Henrykiem, władcą Śląska i Polski. Tego więc szlachetnego męża poślubiła - jak Sara - nie z pożądliwości, lecz z woli Bożej. Zawierając bowiem małżeństwo, czyniła to - jak powszechnie mówiono - wypełniając raczej wolę rodziców aniżeli własną, aby po ustaniu pożycia małżeńskiego najwyraźniej mogła stwierdzić, że już wówczas związała się nie ukrywanym zobowiązaniem do wstrzemięźliwości”" ${ }^{14}$. Jadwiga została

9 B. Zientara, Henryk Brodaty i jego czasy, Warszawa 1975, s. 98. Por. G. M. Baran, P. Nowak, Święta Jadwiga Śląska - patronka dębickiego grodu, s. 33 .

${ }_{10}$ Por. K. Dola, Hedwig, w: Marienlexikon, Hrsg. R. Bäumer, L. Scheffczyk, Bd. 3, St. Ottilien 1991, s. 89.

${ }^{11}$ Jadwiga nabyła tu umiejętność pisania i czytania również w powszechnie wtedy używanej łacinie. Nabyła również różne umiejętności praktyczne. Por. A. Kiełbasa, Święta Jadwiga patronką dnia wyboru Jana Pawła II, Rzym-Trzebnica 1985, s. 19.

${ }_{12}$ Por. W. Bochnak, Z życia i działalności św. Jadwigi Śląskiej, w: Bulla kanonizacyjna św. Jadwigi Śląskiej, wprowadzenie i przekł. S. Rosik, red. W. Bochenek, Legnica-Brzeg Dolny 2014, s. 20. Niektórzy uczeni wykazują, że program nauczania w tego typu szkołach opierał się na wskazaniach pedagogicznych, jakie podał św. Hieronim w ramach swojej korespondencji z przyjaciółmi. Zob. G. M. Baran, P. Nowak, Święta Jadwiga Śląska - patronka dębickiego grodu, s. 34 .

${ }_{13}$ Por. P. Nowak, Święta Jadwiga Śląska - patronka dębickiego grodu, s. 22.

${ }^{14}$ Legenda świętej Jadwigi, s. 30. 
więc żoną księcia Śląska, Krakowa i Wielkopolski, a uroczystość zaślubin mogła mieć miejsce w Andechs lub też w Legnicy albo Wrocławiu. Za datę tego wydarzenia przyjmuje się zazwyczaj lata 1186-119o. Małżeństwo to, choć zawarte z racji dynastyczno-rodowych, okazało się bardzo szczęśliwe ${ }^{15}$. Jadwiga urodziła Bolesławowi siedmioro dzieci - trzy córki: Agnieszkę, Zofię i Gertrudę oraz czterech synów: Bolesława, Konrada, Henryka i syna zmarłego w niemowlęctwie. Wychowała je w bojaźni Bożej oraz na chwałę $\mathrm{kraju}^{16}$. Jednak tylko córka Gertruda przeżyła swoich rodziców, a już w wieku 12 lat wstąpiła do klasztoru cysterek w Trzebnicy, przy którym po śmierci męża mieszkała jej matka. Pozostałe dzieci Jadwigi zmarły w młodzieńczym wieku. Jadwiga starała się - jak podają źródła historyczne - jak najlepiej wypełniać powołanie żony i matki. Wiodła bardzo przykładny i świątobliwy tryb życia. Jej serce było wypełnione także miłością do stanu zakonnego. Dlatego też zapewne w 1209 roku razem ze swoim mężem, w obecności biskupa Wawrzyńca we Wrocławiu złożyła uroczyście ślub wstrzemięźliwości ${ }^{17}$.

Bardzo ważnymi inicjatywami, które obok codziennej pracy podejmowała Jadwiga, były wszelkiego rodzaju fundacje religijno-charytatywne. W 1202 roku namówiła męża do założenia w Trzebnicy żeńskiego klasztoru dla cysterek. Była to pierwsza fundacja klasztorna, którą para książęca sama zrealizowała $^{18}$. Ksienią tego konwentu była od 1232 raż do 1268 roku córka Jadwigi - Gertruda ${ }^{19}$. Jej dziełem jest fundacja klarysek we Wrocławiu, kanoników regularnych św. Augustyna w Nowogrodźcu Bobrzańskim i magdalenek w Nowogrodźcu nad Kwisą. Zainspirowała i ufundowała powstanie szpitala Świętego Ducha we Wrocławiu, który był pierwszym tego rodzaju ośrodkiem w księstwie śląskim, a dla chorych na trąd kobiet ufundowała klasztor w Środzie Śląskiej ${ }^{20}$. Innymi fundacjami Jadwigi były kościoły

${ }_{15}$ Por. K. Bobowski, Przedmowa, w: Legenda świętej Jadwigi, s. 8. Niektórzy historycy nazywają nawet to małżeństwo „politycznym układem”.

${ }^{16}$ Szerzej zob. A. Kiełbasa, Święta Jadwiga Śląska jako wychowawczyni własnych dzieci i swoich wnuków, Trzebnica 1994.

${ }_{17}$ Por. A. Kiełbasa, Święta Jadwiga patronka dnia wyboru Jana Pawła II, s. 20-34.

${ }_{18}$ Por. G. M. Baran, P. Nowak, Święta Jadwiga Śląska - patronka dębickiego grodu, s. 45.

19 Por. K. Bobowski, Przedmowa, w: Legenda świętej Jadwigi, s. 8.

${ }^{20}$ Por. W. Bochnak, Z życia i działalności św. Jadwigi Śląskiej, w: Bulla kanonizacyjna św. Jadwigi Śląskiej, s. 3o. Legenda maior nic nie wspomina o tym, by miał to być klasztor. Czytamy w niej, że trędowate niewiasty mieszkające wspólnie w pobliżu Środy Śląskiej Jadwiga każdego 
w Leśnicy koło Wrocławia, Bolesławcu i Złotym Stoku. Fundowane przez siebie kościoły, jak również i inne świątynie wyposażała w naczynia oraz szaty liturgiczne. Warto wspomnieć, że owe szaty wykonywane były przez nią samą lub przez jej dworki w pracowni, która słynęła w tamtych czasach z wysokiego poziomu artystycznego.

Rozgłos Elżbiety Węgierskiej, jej siostrzenicy, oraz kazania franciszkanów skłoniły Jadwigę do życia w ascezie i do ofiarności na rzecz ubogich, których darzyła szczególną miłością. Skromnie ubrana i chodząca boso, nie różniła się od biedaków, którym niosła pomoc. Śpiesząc z pomocą ubogim, stworzyła dla nich oddzielną służbę, świadczyła jałmużnę, między innymi obdarowując poddanych i spłacając za nich długi. Na sądy posyłała ku obronie kapłanów, gdyż obawiała się, że poddanym może stać się krzywda. Dla chorych i ubogich fundowała szpitale i przytułki ${ }^{21}$.

Ostatnie lata Jadwigi były naznaczone bardzo bolesnymi doświadczeniami. 19 marca 1238 roku na zamku w Krośnie Odrzańskim zmarł jej mąż Henryk Brodaty. Śmierć męża przyjęła z poddaniem się woli Bożej. Wówczas to zamieszkała obok trzebnickiego klasztoru. Już w niecałe trzy lata później spadło na nią kolejne trudne doświadczenie. W 1241 roku, w czasie najazdu mongolskiego, zginął w bitwie pod Legnicą jej najstarszy syn, dziedzic książęcego tronu - Henryk iI Pobożny ${ }^{22}$.

W połowie roku 1243 Jadwiga poważnie zachorowała. Wyczerpana ostrą ascezą pokutną, przeczuwając bliski koniec, poprosiła o sakrament namaszczenia. Zmarła w opinii świętości 14 października 1243 roku w godzinach wieczornych. Dwa dni później została pochowana w trzebnickim kościele klasztornym w kaplicy św. Piotra ${ }^{23}$.

tygodnia obdarowywała pieniędzmi, jedzeniem i odzieżą oraz wszystkim, co było im potrzebne, troszcząc się o nie jak o swoje córki. Por. Legenda świętej Jadwigi, s. 6o.

${ }^{21}$ Por. G. M. Baran, P. Nowak, Święta Jadwiga Śląska - patronka dębickiego grodu, s. 44-47.

${ }_{22}$ Por. W. Bochnak, $Z$ życia i działalności św. Jadwigi Śląskiej, s. 32; K. Bobowski, Przedmowa, w: Legenda świętej Jadwigi, s. 10.

${ }^{23}$ Por. K. Bobowski, Przedmowa, s. 10. W źródłach występuje rozbieżność co do daty śmierci Jadwigi. Niektóre z nich (np. cytowany już Marienlexikon czy też również Bulla kanonizacyjna papieża Klemensa IV) podają datę 15 października 1243 roku. Wynika to stąd, iż w Legenda maior czytamy, że Jadwiga zmarła w dniu Id październikowych, które wypadają 15 dnia miesiąca. Faktycznie jednak Jadwiga zmarła 14 października 1243 roku. Wydanie krytyczne tekstu bulli, zawarte jest w: Schlesisches Urkundenbuch, Bd. 4: 1267-1281 im Auftr. der Historischen Kommission für Schlesien, nr 15, Hrsg. H. Appelt, J. J. Menzel, bearb. W. Irgang, Köln-Wien 1988, s. 18-23. Tłumaczenie na język polski znajduje się w: Bulla kanonizacyjna św. Jadwigi 
Kult Jadwigi zaczął się rozwijać tuż po jej śmierci. Do grobu w trzebnickim kościele ściągały tłumy pielgrzymów z całego Śląska. Przełożona cysterek trzebnickich - Gertruda - udostępniła grób swojej matki dla wszystkich. Wobec uczynków miłosierdzia, które rozsławiły ją za życia szeroko na świecie, oraz wobec licznych uzdrowień przy jej grobie, papież Klemens IV włączył ją w dniu 26 marca 1267 roku w poczet świętych ${ }^{24}$.

\section{Charakterystyka duchowości maryjnej klasztorów żeńskich wczesnego średniowiecza w Polsce}

Święta Jadwiga żyła w czasach wczesnego średniowiecza, dlatego jej duchowość, również duchowość maryjna ${ }^{25}$, w swych fundamentach opierała się na współczesnej jej pobożności. $Z$ tego też powodu wydaje się zasadne przyglądnięcie się średniowiecznej duchowości, aby potem na jej tle ujrzeć specyfikę pobożności maryjnej św. Jadwigi.

\section{Duchowości maryjna $w$ żeńskich klasztorach wczesnego średniowiecza}

We wczesnym średniowieczu z dogmatów maryjnych był ogłoszony tylko dogmat o Bożym macierzyństwie Maryi. Z czasem krystalizowała się nauka dotycząca pozostałych dogmatów, zwłaszcza doktryna o niepokalanym poczęciu. Trzeba jednak zauważyć, że już w tym czasie kult Matki Bożej był bardzo silny. Mówiąc o kulcie Matki Bożej w średniowieczu, możemy przedstawiać jego liturgiczne przejawy, jak też pobożność maryjną ${ }^{26}$. Jest to jednak pole do bardzo szerokich badań, co nie jest celem niniejszego

Śląskiej, wprowadzenie i przekł. S. Rosik, red. W. Bochenek, Legnica 2014, s. 69-86. W dalszej części tekstu przy odwoływaniu się do bulli będzie używane jedynie polskie tłumaczenie.

${ }^{24}$ Por. K. Dola, Hedwig, w: Marienlexikon, s. 89.

${ }_{25}$ Według Leksykonu duchowości katolickiej maryjna duchowość bada tajemnice życia Maryi pod kątem chrześcijańskiego życia duchowego. Maryjna duchowość nie ogranicza się do oddawania czci Matce Bożej, lecz przede wszystkim czerpie z niej przykład wiary, nadziei i miłości, czym istotnie różni się od pobożności maryjnej. Zob. A. Rybicki, Maryjna duchowość, w: Leksykon duchowości katolickiej, red. M. Chmielewski, Lublin-Kraków 2002, s. 493. W niniejszym artykule jednak obydwa pojęcia maryjnej duchowości i pobożności będą używane zamiennie i nie będą ograniczały się tylko do oddawania czci Maryi, ale także do Jej naśladowania.

${ }^{26}$ Por. J. Nowak, Maryja w liturgii i pobożności Kościoła, Poznań 2009. O kulcie Maryi na ziemiach polskich zob. Z. Janiec, Kult Maryi w Polsce na przestrzeni dziejów..., passim. 
artykułu. W zakonach średniowiecznych z pewnością przejawiały się obie formy tego kultu: we wspólnie sprawowanej liturgii, a pobożność ludowa bez wątpienia znajdowała swe odzwierciedlenie w osobistych modlitwach mniszek. Autorzy charakteryzują duchowość maryjną na podstawie analizy modlitw mniszek z tamtych czasów. Część z nich jednak uważa, że bardzo trudno jest cokolwiek sensownego orzec o tej duchowości ${ }^{27}$.

Źródłami, z których poznajemy duchowość w zakonach żeńskich wczesnego średniowiecza, są przede wszystkim modlitewniki wykorzystywane przez mniszki. Bardzo cenne byłyby również pisma własne zakonnic - te jednak prawie w ogóle się nie zachowały ${ }^{28}$. Do naszych czasów zachowały się jedynie szczątki zasobów z księgozbiorów wrocławskich i głogowskich klarysek, legnickich benedyktynek oraz trzebnickich cysterek ${ }^{29}$. Innymi źródłami, z których można zaczerpnąć trochę wniosków, mogą być także księgi liturgiczne i pozaliturgiczne. Pierwszorzędną szkołą duchowości była modlitwa liturgiczna, a więc przede wszystkim psałterz. Na nich opierała się modlitwa osobista mniszek ${ }^{30}$, które w duchowości maryjnej znajdowały możliwość wyrażenia swojej szczególnej wrażliwości religijnej.

Analizując wszystkie wymienione powyżej źródła, można dojść do wniosku, że Maryja była czczona przede wszystkim jako obdarzona szczególną łaską. Dostąpiła ona godności Bożego rodzicielstwa i stąd wypływało jej szczególne miejsce wśród wszystkich stworzeń. Mniszki w modlitwach prosiły Maryję, aby mogły tak jak ona adorować Jezusa i zawsze być obok Niego. Wizerunek Matki Bożej wyłaniający się z tych analiz zachowuje wielką poprawność teologiczną. Warte uwagi jest również to, że Maryja była kimś więcej niż świętą, ale nie cieszyła się przymiotami boskimi. Wątek współudziału Maryi w dziele odkupienia pozostawał prawie nieobecny. Maryja była wzywana jako święta, słodka i błogosławiona. Ukazywano ją jako Świętą bramę otwartą dla wszystkich pragnących zbliżyć się do jej boskiego Syna. Była postrzegana jako ktoś, kto znajdował się bliżej ludzkich spraw niż sam Bóg. Przez to ośmielano zanosić się przez jej wstawiennictwo modlitwy i prośby w codziennych ludzkich potrzebach, nawet często beznadziejnych.

${ }_{7}$ Zob. M. Borkowska, Duchowość polskich klasztorów żeńskich w średniowieczu, s. 111.

${ }^{28}$ Por. M. Borkowska, Duchowość polskich klasztorów żeńskich w średniowieczu, s. 112.

${ }^{29}$ Zob. A. Sutowicz, Maryja $w$ duchowości ślaskich klarysek i benedyktynek $w$ okresie średniowiecza, „Perspectiva. Lednickie Studia Teologiczno-Historyczne” 10 (2011) nr 1, s. 210.

${ }^{30}$ Por. M. Borkowska, Duchowość polskich klasztorów żeńskich w średniowieczu, s. 113-116. 
Wyrażano przez to przekonanie, że Maryja jest Matką Miłosierdzia i że Ona nikogo nie pozostawia bez wysłuchania. Oprócz Pośredniczki łask Maryja była postrzegana jako niedościgniony wzór świętości kobiet poświęconych Bogu. Dlatego też wpatrywanie się w nią stanowiło niejako funkcję wychowawczą i inspirującą do zachowywania reguł zakonnych. Jednak postawa matki Jezusa pozostawała niedościgniona, ponieważ nie wypływała $\mathrm{z}$ narzuconej sobie przez Maryję ascezy ani nie wynikała z podjętych ćwiczeń duchowych, ale była następstwem szczególnego wybrania przez Boga ${ }^{31}$.

\section{Maryjna duchowość benedyktynów}

Jak zostało wspomniane, św. Jadwiga wykształcenie odebrała w klasztorze benedyktyńskim w Kitzingen. Spędziła tam siedem lat swojego życia. Zatem to duchowość mniszek żyjących według reguły św. Benedykta z Nursji wywarła na nią duży wpływ.

Święty Benedykt (†547) około 529 roku udał się na Monte Cassino i tam dla swoich uczniów napisał Regułę $e^{32}$, która potem stała się podstawą dla wielu rodzin monastycznych. Regułę tę kojarzy się często z hasłem „ora et labora”, choć tego zdania w niej nie ma. Pojawiło się ono dopiero 300 lat po śmierci św. Benedykta. Święty, tworząc regułę, chciał przede wszystkim przystosować życie zakonne do mentalności zachodniej. Nawiązywał przy tym do czasów apostolskich i życia pierwszych gmin. Kiedy papież Paweł vi ogłaszał św. Benedykta patronem Europy, określił trzy elementy działalności zakonu jako: „krzyż, książkę i pług”33. Święty Benedykt w swojej Regule nie wspomina nic o Matce Bożej. Podobnie jego biograf - św. Grzegorz Wielki nie mówi o jego maryjnej pobożności. Jednak, według tradycji, św. Benedykt jako młody student w Rzymie często modlił się przed obrazem Matki Bożej. To opowiadanie wpływało bardzo mocno na życie mnichów, którzy w Maryi widzieli wzór oddania się, poświęcenia Bogü4.

${ }^{31}$ Zob. A. Sutowicz, Maryja $w$ duchowości śląskich klarysek i benedyktynek $w$ okresie średniowiecza, s. 212-222.

${ }^{32}$ Św. Benedykt z Nursji, Reguła. Żywot. Komentarz, Tyniec 1979.

${ }_{33}$ Zob. M. Chmielewski, E. Walewander, Benedyktyńska szkoła duchowości, w: Leksykon duchowości katolickiej, s. 74-77.

${ }^{34}$ Zob. Ph. Schmitz, F. Renner, Benediktiner, w: Marienlexikon, Hrsg. R. Bäumer, L. Scheffczyk, Bd. 1, St. Ottilien 1988, s. 425-426. 
Cześć dla Matki Bożej i swoją naukę o niej benedyktyni wyrażali głównie poprzez liturgię. Maryjnym okresem był dla zakonników benedyktyńskich adwent. Uroczystość Wniebowzięcia Maryi była przez nich stawiana na równi z Wielkanocą i Zesłaniem Ducha Świętego. Benedyktyni jako pierwsi zaczęli świętować sobotę jako dzień maryjny, a od xi wieku wprowadzili w ten dzień oficjum maryjne. $Z$ tego zakonu wywodzi się też najprawdopodobniej zwyczaj dodawania do komplety antyfony maryjnej. W wielu opactwach panował zwyczaj polegający na tym, że gościa, który odwiedzał klasztor, zaprowadzano przed obraz Matki Bożej i wspólnie z nim odmawiano jakąś modlitwę do Maryi. Istniało też wskazanie, aby w każdym benedyktyńskim kościele znajdował się jeden ołtarz poświęcony Matce Bożej. To, że benedyktyni świętowali swoje patronackie święta wspólnie z ludem, sprawiało, że mieli wielki wpływ na ludową pobożność maryjną. Przez wiernych Matka Boża była czczona szczególnie jako Ucieczka grzeszników i Matka Miłosierdzia, a kościoły bądź kaplice z obrazami o tych tytułach często stawały się miejscami pielgrzymowania ${ }^{35}$.

\section{Maryjna duchowość cystersów}

Choć księżna śląska swoje wykształcenie odbierała w szkole benedyktyńskiej, to jednak później związała się z zakonem cysterskim, a jego duchowość stała się jej bardzo bliska ${ }^{36}$.

Zakon cystersów powstał w 1098 roku we Francji w Cîteaux, w wyniku reformy benedyktyńskiej reguły. Jego żeńska gałąź w roku 1125 w Tart. Założycielami zakonu byli św. Robert z Molesme (†1110), św. Alberyk (†1109) i św. Stefan Harding (†1134). Nowy zakon rozwijał się bardzo szybko, już w pół wieku od założenia posiadał aż 70 opactw ${ }^{37}$. Pierwszym żeńskim

35 Por. Ph. Schmitz, F. Renner, Benediktiner, s. 428-430.

${ }^{36}$ Papież Klemens IV w Bulli kanonizacyjnej pisze: „A chociaż w przestrzeganiu tego, co dotyczy zasad reguły [zakonnej] - tak dalece jak przystało jej stanowi - wyprzedzała wszystkie mniszki, jednak odmówiła złożenia ślubów profesji zakonnej i ogłoszenia tego w należyty sposób, nie z innego [wszelako] powodu - jak wieść niesie - jak tylko po to, by miała skąd wyciągać dłoń ku biednemu i otwierać prawicę szczodrobliwości wobec potrzebującego" (Bulla kanonizacyjna św. Jadwigi Śląskiej, s. 73).

${ }^{37}$ Por. I. Kapera, J. Kapera, Opactwa cysterskie $w$ Polsce $i$ ich wplyw na rozwój turystyki, „Peregrinus Cracoviensis” 25 (2014) nr 3, s. 80-81. Szerzej na temat historii zakonu cystersów: H. Kostrzański, Dziedzictwo białych mnichów, Szczyrzyc 1991. 
klasztorem na ziemiach polskich było opactwo trzebnickie ufundowane przez św. Jadwigę wraz z mężem. Ogólnie można stwierdzić, że duchowość cysterska wywodzi się z syntezy tradycji benedyktyńskiej i eremickiej. Jej fundamenty opierały się na trzech zasadach: surowym i pełnym przestrzeganiu Reguły św. Benedykta, skrajnym ubóstwie i eremickim stylu życia ${ }^{38}$.

Największy wpływ na rozwój zakonu miał jego najznamienitszy przedstawiciel - św. Bernard z Clairvaux $(\dagger 1153)^{39}$. Odznaczał się on gorącym nabożeństwem do Najświętszej Maryi Panny. W nauczaniu o Maryi często podkreślał jej miłosierdzie i zachęcał do wielkiej ufności w jej pośrednictwo $\mathrm{u}$ Boga ${ }^{40}$. Wywarł przez to wielki wpływ na dewocyjny nurt w mariologii ${ }^{41}$.

Cześć oddawana Matce Bożej należy do istoty duchowości cysterskiej. Niektórzy z autorów doszukują się nawet początków modlitwy różańcowej właśnie w zakonie cysterskim ${ }^{42}$. Miejsca, w których wznosili swoje opactwa, na terenach nizinnych były nazywane Dolinami Maryi, a klasztory nosiły nazwę Domów Maryi. Kościoły cysterskie jako pierwsze swoje wezwanie otrzymywały wezwanie maryjne. Matka Boża Wniebowzięta jest patronką całego zakonu ${ }^{43}$.

${ }^{38}$ Zob. B. A. Grenz, Cysterska szkoła duchowości, w: Leksykon duchowości katolickiej, S. 150-154.

${ }^{39}$ Urodzony w 1090 roku w okolicach Dijon w Burgundii, Bernard, w wieku 23 lat, po śmierci matki, przekonał stryja, czterech braci i dwudziestu pięciu dalszych krewnych do wstąpienia do upadającego opactwa cystersów w Citeaux, z zamiarem powrotu do pierwotnego ducha reguły benedyktyńskiej. Po trzech latach został skierowany do Clairvaux w Szampanii, gdzie wybudował klasztor, którego został opatem i w którym rozpoczął wprowadzanie w życie swojej reformy. Do swej śmierci w roku 1153 założył 68 klasztorów, a 16o innych podporządkował swojej władzy. Por. A. Andrzejuk, Mistyka miłości Bożej w pismach św. Bernarda z Clairvaux, „Studia Philosophiae Christianae" 47 (2011) nr 2, s. 63-102.

${ }^{40}$ Św. Bernardowi przypisuje się autorstwo modlitwy do Matki Bożej: Pomnij, o Najświętsza Panno Maryjo. Tradycja mówi też, iż jest on autorem słów kończących antyfonę: Witaj Królowo, Matko miłosierdzia.

${ }^{41}$ Papież Pius XII w 8oo. rocznicę śmierci świętego opublikował encyklikę Doctor Mellifluus w uznaniu jego wielkich zasług dla Kościoła. Por. Pius xiı, Doctor Mellifluus. O świętym Bernardzie z Clairvaux, Warszawa 2004. Papież poświęca trzy ostatnie punkty encykliki miłości św. Bernarda do Najświętszej Maryi Panny, codziennemu wzbudzaniu miłości do Bożej Rodzicielki i przykładowi świętego, który błagał o pomoc Maryję w każdej potrzebie.

${ }^{42}$ Zob. A. Heinz, Uwielbienie Misteriów jako pierwotna intencja Różańca Świętego, „Jasna Góra" $1985 \mathrm{nr}$ 10, s. 4-8.

${ }^{43}$ Zob. K. Jackiewicz, Kult Matki Bożej w zakonie cystersów, „Jasna Góra” 1986 nr 9, s. 26. 
Cystersi w swojej duchowości podkreślali rolę Maryi jako pośredniczki ${ }^{44}$. Propagatorem Maryi jako pośredniczki w powszechnym rozdawnictwie łask był Bernard z Clairvoux. Uważał on, że skoro przez Maryję Chrystus przyszedł na świat, to również właśnie przez Maryję człowiek może dojść do Chrystusa. Święty Bernard z Clairvaux sprawiedliwości Chrystusa przeciwstawiał miłosierdzie Maryi. Wyrazem takiego myślenia i tego nurtu jest jego modlitwa „Pomnij, o Najświętsza Panno Maryjo, że nigdy nie słyszano.... Natomiast inny cysters Guerricus z Igny (†1157) uznawał Maryję za wzór duchowy w naśladowaniu Chrystusa i twierdził, że przez narodzenie Chrystusa w duszy dusza staje się matką Chrystusa na wzór Maryi. Jest to echem tezy Augustyna, wedle której poczęcie, dokonane w ciele Maryi, realizuje się według ducha w sercu dziewic ${ }^{45}$.

Pobożność maryjna w zakonie cysterskim wyrażała się bardzo mocno również poprzez sztukę. Kult Maryi, będący cechą charakterystyczną pobożności cysterskiej, wpłynął na to, że zakonny zakaz dotyczący przedstawień figuralnych nie obejmował Matki Bożej z Dzieciątkiem. Właśnie dzięki cystersom w ikonografii maryjnej pojawił się nowy motyw - Matki Miłosierdzia z płaszczem opieki. Motyw ten został później szeroko rozpowszechniony ${ }^{46}$. Cysterska duchowość podkreślała rolę Maryi jako pośredniczki prowadzącej do Chrystusa i wspomagającej duchowy wzrost człowieka ${ }^{47}$.

\section{Maryjna duchowość franciszkanów}

Także duchowość zakonu franciszkanów miała wpływ na formowanie się pobożności św. Jadwigi. Korzystała ona bowiem z posługi franciszkańskiego spowiednika Herborda ${ }^{48}$.

${ }^{44}$ Szerzej na temat tego, jak należy rozumieć pośrednictwo Maryi zob. J. Lekan, Pośredniczka w Chrystusie, „Salvatoris Mater” 4 (2002) nr 3, s. 86-112.

${ }^{45}$ Por. M. Daniluk, Maryjność a maryjności. Różnorodność maryjnych aspektów duchowości zakonnej, „Summarium. Sprawozdania TN KUL” 20-21 (1991-1992), s. 75-76.

${ }^{46}$ Szerzej na ten temat zob. R. Knapiński, Od pokrowy do płaszcza opieki. Przeobrażenia motywu ikonograficznego Mater Misericordiae, „Studia Warmińskie” 39 (2002), s. 131-16o.

${ }_{77}$ Por. M. Daniluk, Maryjność a maryjności. Różnorodność maryjnych aspektów duchowości zakonnej, s. 75-76.

${ }^{48} \mathrm{Na}$ podstawie tekstu Legenda maior wiemy, iż spowiednik ten interweniował w kwestie surowej ascezy Jadwigi. Zob. Legenda świętej Jadwigi, s. 46. 
Początki duchowości franciszkańskiej są oczywiście związane ze św. Franciszkiem z Asyżu (†1226). Za wydarzenie stojące u początków zakonu franciszkanów ${ }^{49}$ przyjmuje się spotkanie Franciszka (wraz ze swoimi naśladowcami) z papieżem Innocentym III w 1209 roku. Jednak dopiero papież Honoriusz III w 1223 roku zatwierdził spisaną przez Franciszka regułę ${ }^{50}$.

Miłość do Maryi i pobożność maryjna św. Franciszka jest z pewnością głęboka $^{51}$ i oryginalna. Wyrażała się ona przede wszystkim w modlitwie do niej ${ }^{52}$, wysławianiu jej czci w pismach oraz przez szczególne przywiązanie i szacunek do kościółka Matki Bożej Anielskiej, zwanego także Porcjunkulą. W kościółku tym Franciszek gromadził swoich braci na kapituły i on też miał stanowić niejako centrum zakonu franciszkańskiego. Maryja została przez niego wybrana na opiekunkę zakonu. Ulubiony przedmiot refleksji maryjnej dla Franciszka to tajemnica wcielenia Słowa i tajemnica Bożego narodzenia. Cześć, którą święty z Asyżu oddawał Maryi, jest głęboko chrystocentryczna ${ }^{53}$.

Fundamentalnymi ideami duchowości franciszkańskiej są: prawda, że Bóg jest najwyższym dobrem, chrystocentryzm, pobożność eucharystyczna i pobożność maryjna. Franciszkanie często nazywali siebie „Rycerzami

49 Por. K. Klauza, M. Daniluk, Franciszkanie. Geneza i dzieje, w: Encyklopedia katolicka, red. Bieńkowski, P. Hemperek i in., t. 5. Lublin 1989, kol. 474-477.

5o Szerzej na ten temat zob. K. Klauza, Franciszkańska reguła, w: Encyklopedia katolicka, t. 5, kol. 564-566.

${ }^{51}$ Podkreśla to pierwszy biograf św. Franciszka - Tomasz z Celano: „Matkę Jezusa darzył niewysłowioną czcią za to, że Pana majestatu uczyniła naszym bratem. Odprawiał do Niej osobne chwalby, zanosił modlitwy, ofiarowywał uczucia, tak wiele ich i takich, że ludzki język nie zdoła wypowiedzieć” (T. Słotwiński, Trójca Święta a Maryja u św. Franciszka z Asyżu $i$ św. Antoniego z Padwy, „Salvatoris Mater” 2 [200o] nr 3, s. 269).

${ }^{52}$ Święty Franciszek jest autorem kilku modlitw do Matki Bożej. Są to m.in.: Pozdrowienie Błogosławionej Maryi Dziewicy (zob. Św. Franciszek, św. Klara z Asyżu, Pisma, Skultuna 20o8, s. 96), jak również antyfona maryjna odmawiana przez niego przy każdej modlitwie brewiarzowej: „Święta Maryjo, Dziewico, wśród niewiast na świecie nie urodziła się podobna Tobie, Córko i Służebnico najwyższego Króla, Ojca niebieskiego, Matko najświętszego Pana naszego Jezusa Chrystusa, Oblubienico Ducha Świętego: módl się za nami wraz ze św. Michałem Archaniołem i wszystkimi mocami nieba, i wszystkimi świętymi do Twego najświętszego, umiłowanego Syna, Pana i Mistrza" (Św. Franciszek, św. Klara z Asyżu, Pisma, s. 108).

${ }_{33}$ Por. T. Słotwiński, Trójca Święta a Maryja u św. Franciszka z Asyżu i św. Antoniego $z$ Pa$d w y$, s. 268-29o. 
Niepokalanej", a Maryja zajmuje w teologii i duchowości franciszkańskiej uprzywilejowaną pozycję $e^{54}$.

\section{Pobożność maryjna w życiu św. Jadwigi}

Niewiele mamy źródeł na temat pobożności maryjnej św. Jadwigi. Z relacji jednego z najstarszych zachowanych tekstów źródłowych, czyli Legenda maior, nie dowiadujemy się zbyt wiele. Dużo więcej możemy powiedzieć, biorąc pod uwagę cały kontekst epoki.

\section{Duchowość maryjna wypływająca $z$ duchowości zakonnej}

Święta Jadwiga wychowana została w klasztorze benedyktyńskim w Kitzingen. Był to czas głębokiej formacji duchowej. Choć autor Legenda maior nigdzie o tym wprost nie wspomina, z pewnością musiała ona żyć duchowością tego zakonu, a po ufundowaniu klasztoru trzebnickiego związała się z duchowością cysterską, która wypływa z benedyktyńskiej5. Duchowość maryjna tych dwóch zakonów w przypadku księżnej śląskiej została ubogacona dodatkowo wpływami franciszkańskimi, ponieważ to właśnie $\mathrm{z}$ tego zakonu wywodził się spowiednik Jadwigi. Jak zostało to wykazane w drugim punkcie, kult i cześć dla Matki Bożej w duchowości benedyktynów wyrażały się przede wszystkim przez liturgię. Duchowość cysterska i franciszkańska to przede wszystkim modlitwa do Matki Bożej i jej naśladowanie w swoim życiu. Wszystko to jest widoczne w życiu Jadwigi, która umiłowała modlitwę liturgiczną ${ }^{56}$, a cnoty Matki Bożej starała się rozwijać.

\section{Duchowość maryjna św. Jadwigi w małżeństwie}

Bardzo ważnym elementem duchowości św. Jadwigi było jej dążenie do czystości, także w małżeństwie. Księżna śląska wraz z mężem po urodzeniu się ostatniego dziecka podjęła decyzję o całkowitej wstrzemięźliwości. Autor

${ }^{54}$ Por. H. Lipiński, Zasadnicze idee duchowości św. Franciszka i aktualność franciszkańskiej drogi, „Śląskie Studia Historyczno-Teologiczne” 10 (1977), s. 169-175.

${ }_{55}$ Zob. G. M. Baran, P. Nowak, Święta Jadwiga Śląska - patronka dębickiego grodu, s. 51.

${ }_{56}$ Tematowi modlitwy poświęca autor Legenda maior cały v rozdział O modlitwie i o umiłowaniu Boga przez Jadwigę. Zob. Legenda świętej Jadwigi, s. 50-57. 
Legenda maior tak opisuje ten fakt: „A ponieważ ci szczęśliwi małżonkowie żyli w zbożnej myśli cnotliwie i w czystości zgodnie z nauką Bożą, aby w ten sposób zasłużyć na większą łaskę Bożą, przeto jednomyślnie i zgodnie postanowili zobowiązać się solennie, $\mathrm{z}$ błogosławieństwem biskupa, iż do końca życia zachowają wstrzemięźliwość. Wspomożeni duchem Bożym przez około 30 lat rozłączeni od łoża, przeżyli w pojedynkę życie ozdobione przedziwnie pięknem czystości. Przez cały ten czas Jadwiga jako służebnica Pańska modliła się jak najżarliwiej, aby tego blasku czystości, który już wtedy był znany ogółowi i bardzo często potwierdzany oczywistymi znakami wobec wielu świadków, nie dotknęło w jakiś sposób oczernianie nieprawej opinii, ludzi grzesznych, którzy z łatwością dopuszczają do siebie materię skandalu i róże dobrych uczynków rozkwitające obok nich ranią oszczerczym językiem jakby ostrzem kolców"57. W chęci zachowywania czystości nawet w małżeństwie możemy pośrednio dopatrywać się woli naśladowania przez księżną śląską w swoim życiu tej, która była najczystsza, czyli Matki Bożej. Należy mieć też na uwadze powstałą w średniowieczu koncepcję małżeństwa duchowego. Jako pierwszy sformułował ją Hugon od św. Wiktora (†1141). Rozważał on kwestię małżeństwa Maryi i Józefa, która to była jednym z kluczowych problemów wśród rozważań teologicznych na temat kultu Matki Bożej. Skoro Matka Jezusa była dziewicą, to związek Józefa i Maryi był małżeństwem duchowym, a o jego ważności stanowiła zgoda wyrażona przez małżonków ${ }^{58}$. Biorąc więc pod uwagę ogólny kontekst epoki, w której żyła Jadwiga, możemy pośrednio wnioskować, że powstrzymywanie się od kontaktów seksualnych, zachowywanie czystości i wstrzemięźliwości również w małżeństwie przez śląską księżną było powodowane chęcią naśladowania Matki Bożej. Niejako potwierdzeniem tej tezy jest wyjaśnienie przez autora Legenda maior powodów zachowywania przez Jadwigę wstrzemięźliwości. Otóż czyniła to ze względu na szczególny kult świętych, którym ta wstrzemięźliwość była miła ${ }^{59}$.

57 Legenda świętej Jadwigi, s. 31-32.

${ }^{58}$ Zob. M. Michalski, Coitus albo consensus, czyli co stanowi o ważności małżeństwa. Relacja $z$ pewnej dyskusji $z$ XI-XIII wieku, w: Nihil superfluum esse. Prace z dziejów średniowiecza ofiarowane Profesor Jadwidze Krzyżaniakowej, red. J. Strzelczyk, J. Dobosz; współpr. Z. Górczak i in., Poznań 200o, s. 163-164.

59 „Non enim reputabat gratam esse veneracionem sanctis exhibitam nec deo acceptum fore ieiunium, quod cum oblectamentis carnalibus celebratur" (Monumenta Poloniae Historica. Pomniki dziejowe Polski, t. 4, s. 515). Zob. Legenda świętej Jadwigi, s. 31. Więcej na temat po- 
Analizując życie św. Jadwigi, dowiadujemy się, że wraz z mężem ufundowała wiele kościołów. Część z nich była poświęcona Matce Bożej lub też znajdował się w nich ołtarz ku czci Maryi. Potwierdzeniem powyższej tezy, jak również tego, iż w kościele w Trzebnicy - ufundowanym w całości przez śląską księżną i męża - był ołtarz Matki Bożej, jest tekst Legenda maior mówiący: „Między innymi uczynkami miłosierdzia za najważniejsze uważała dzieło pobożności w rozszerzaniu zbawienia dusz i dlatego radami i zachęcaniem doprowadziła małżonka do tego, iż własnym kosztem zbudował klasztor w Trzebnicy dla mniszek zakonu cysterskiego. [...] Wspomniany kościół i klasztor został ufundowany na cześć Wszechmocnego Boga i przesławnej Dziewicy Maryi oraz świętego Apostoła Bartłomieja w roku Pańskim 1203, a poświęcony w roku Pańskim 1219"60. Natomiast w innym miejscu autor Legenda maior wspomina o modlitwie, którą zanosiła Jadwiga przed ołtarzem Matki Bożej w trzebnickim kościele: „Zdarzyło się, że jedna z zakonnic klasztoru trzebnickiego zapragnęła przekonać się, w jaki sposób służebnica Chrystusowa, pozostając w samotności, oddaje się pobożnym praktykom; gdy inne zakonnice leżały w sypialniach, potajemnie weszła do kościoła i zobaczyła Świętą, która przechodząc składała zbożne pocałunki na poszczególnych klęcznikach i miejscach, których dotykały stopy sióstr. Zwykłym obyczajem Jadwiga zwróciła się do Stwórcy o łaskę dla wszystkiego, co wystawiono w tym kościele przed ołtarzem ku czci chwalebnej Dziewicy, na którym wznosił się wysoki krucyfiks, wyraziście odtwarzający Ukrzyżowanego i budzący dla Niego cześć" ${ }^{61}$.

\section{Figurka Matki Bożej}

Bardzo istotnym faktem, który świadczy o maryjnej pobożności św. Jadwigi, jest zwyczaj noszenia przez księżną obrazka bądź figurki Matki Bożej. Autor Legenda maior wspomina o tym trzy razy. Po raz pierwszy czyni to, kiedy mówi o czci Jadwigi wobec świętych Pańskich, spośród których Matka Boża była przez nią otaczana największą miłością: „Wśród wszystkich świętych szczególną miłością otaczała, jak być powinno, Matkę Chrystusową i dlatego

wodów wstrzemięźliwości w małżeństwie św. Jadwigi zob. M. Michalski, Vita perfecta. Wzorce świętości w żywotach trzynastowiecznych księżnych polskich, Poznań 2001, s. 145-174.

${ }^{60}$ Legenda świętej Jadwigi, s. 58.

${ }^{61}$ Legenda świętej Jadwigi, s. 36-37. 
nosiła przy sobie Jej mały obrazek na kości słoniowej. Często brała go do ręki, aby w miłości do Matki Boskiej na Nią spojrzeć i dzięki temu spojrzeniu wzbudzić w sobie jeszcze większe uwielbienie dla Panny Wsławionej. Tym obrazkiem kiedyś Jadwiga pobłogosławiła chorych, którzy natychmiast wyzdrowieli, a obrazek został uznany za cudowny. Fakt ten zapisano dla pamięci wszystkich, do jak wielkich i wzniosłych zasług doszła już Jadwiga, która w żarliwej miłości do Matki Syna Bożego nieustannie nosiła przy sobie Jej obrazek"62. W łacińskim oryginale tekst ten brzmi następująco:

Matrem vero domini inter alios sanctos, quia maiori, ut dignum errat, amplexabatur amore, ideo ipsius parvam semper apud se gerebat ymaginem quam eciam sepe accipiens in manibus deferebat, ut ex dilectione sepius eam posset respicere et respiciendo devocius se valeret ad amorem gloriose virginis amplius excitare. De qua ymagine dum aliquando benediceret languidos, protinus curabunt, ut sic miraculorum virtute comprobaretur et innotesceret omnibus, ad quantam meritorum celsitudinem illa iam pervenerat, que ex forvere caritatis hanc filii dei motris sedule secum ymaginem deportabat ${ }^{63}$.

Po raz drugi o fakcie noszenia przez Jadwigę obrazka Matki Bożej dowiadujemy się z rozdziału viI $O$ cudach za życia świętej Jadwigi, gdzie możemy przeczytać: „Wieloma jeszcze innymi sławnymi czynami Pan Bóg wywyższył Swoją świętą w jej życiu, na przykład przemieniając wodę w wino lub sprawiając, że idąca boso księżna ukazała się oczom małżonka w obuwiu, o czym wspomina się w rozdziale o skromnym trybie życia św. Jadwigi, a także, że poraziła blaskiem niebieskim swego służącego i że wizerunkiem Matki Boskiej uleczyła wiele osób, o czym opowiedziano w rozdziale v o jej modlitwach” ${ }^{64}$. Zwrot „i że wizerunkiem Matki Bożej uleczyła wiele osób” w łacińskim oryginale brzmi: „[...] et quod ymagine beate virginis multos curavit $[\ldots]]^{165}$.

Ostatni raz autor Legenda maior mówi o obrazku Matki Bożej w ręce św. Jadwigi, opisując przenosiny jej ciała z miejsca jej tymczasowego pochówku do kościoła w Trzebnicy. „[...] po odrzuceniu ziemi z mogiły i uniesieniu

\footnotetext{
${ }^{62}$ Legenda świętej Jadwigi, s. 55.

${ }_{63}$ Monumenta Poloniae Historica. Pomniki dziejowe Polski, t. 4, s. 541.

${ }^{64}$ Legenda świętej Jadwigi, s. 69.

${ }_{65}$ Monumenta Poloniae Historica. Pomniki dziejowe Polski, t. 4, s. 557.
} 
górnej płyty sarkofagu, w którym leżało święte ciało, rozpłynęła się wokoło woń o tak wielkiej sile i takiej słodyczy, że dusze stojących wokół zostały wprawione w podziw i radość. Gdy podniesiono z ziemi kości świętego ciała, okazało się, że mięśnie zanikły i rozpadły się wiązadła członków. Tylko trzy palce lewej ręki świętej zachowały się całkowicie nietknięte: trzymały one w uścisku figurkę Najświętszej Panny. Figurkę tę św. Jadwiga za życia często z sobą nosiła i gdy ją po śmierci chowano, nie można jej było z dłoni wyjąć, bo umierająca tak silnie zacisnęła palce. Przeto cuda, które dokonywane były przy pomocy owej figurki, o czym była już mowa, nabrały teraz nowego potwierdzenia, ponieważ Matka Boża zachowała od zniszczenia ściskające Jej figurkę palce przez tak długi czas" ${ }^{\prime 66}$. Łaciński tekst Legenda maior mówi o tym w następujących słowach:

Nam eiecta humo de tumulo remotaque superiori tabula de sarcophago, in quo corpus sanctum iacebat, odor tanti vigoris et tam suavissimus emanavit, ut omnium illic existencium mentes in ammiracionem commutaret et gaudium. Sacri quoque corporis ossa dum levarentur a terra, consumptis carnibus menbrorumque compage soluta, tres digiti sinistre manus ipsiua inventi sunt totaliter integri, intra se clausam retinentes beate virginis ymaginem parvulam, quam, dum viveret, secum frequenter portaverat cum defuncta fuerat tumulata, quia moricus odeo eam inter inncturas predictorum compresserat digitorum, quod abinde extrahi non poterat bono modo. Illa ergo, que superius recitontur facta, tune novum sumpserunt augmentum, dum mater incorrupta ymaginis sue retimacula tanto tempore a corrupcionis vicio preservavit intacta ${ }^{67}$.

Bardzo znamienny jest fakt, że autor Legenda maior we wszystkich miejscach używa tego samego łacińskiego terminu ymaginem, pochodzącego od słowa imago, które posiada następujące znaczenia: „obraz, podobizna, wizerunek, portret" ${ }^{\prime 6}$. Warto wspomnieć, że w Kodeksie Trzebnickim znajduje się dookreślenie owego ymago - ymago eurnea ${ }^{69}$. Przymiotnik eburneus oznacza natomiast „wykonany z kości słoniowej, albo ozdobiony kością

\footnotetext{
${ }^{66}$ Legenda świętej Jadwigi, s. 120-121.

${ }^{67}$ Monumenta Poloniae Historica. Pomniki dziejowe Polski, t. 4, s. 631.

${ }^{68}$ Słownik łacińsko-polski, red. M. Plezia, t. 3, Warszawa 2007, s. 32.

${ }^{69}$ Słownik łacińsko-polski, t. 3, s. 541. Litera T oznacza kodeks trzebnicki Legendy.
} 
słoniową, a w sposób przenośny biały jak kość słoniowa”7o. Nie możemy stwierdzić, czy Jadwiga nosiła przy sobie obrazek Matki Bożej ozdobiony kością słoniową, bądź też figurkę Maryi wykonaną z tego materiału, czy może jakąś „płaskorzeźbę” przedstawiającą podobiznę Matki Bożej. Ponieważ jednak Jadwiga była głęboko inspirowana duchowością cysterską, można domniemywać, że była to właśnie figurka Matki Bożej. Cystersi, mimo że zakazywali figuralnych przedstawień świętych, nie stosowali tego zakazu do Maryi, dodatkowo to właśnie oni rozpowszechnili tytuł Matki Miłosierdzia. Potwierdzeniem rozumienia ymaginem jako figurki jest średniowieczny zwyczaj wykonywania z kości słoniowej figurek do przechowywania Eucharystii ${ }^{71}$. Kość słoniowa w wiekach średnich miała wartość równą złotu i była wykorzystywana do wykonywania najcenniejszych przedmiotów. Jej kolor - alabastrowej bieli - który nigdy się nie zmieniał, miał symbolizować czystość Maryi ${ }^{72}$. Wszystko to sprawiało, że właśnie wieżowe pyxis ${ }^{73}$ z kości słoniowej, inspirowane symboliką maryjną, było bardzo popularne we wczesnym średniowieczu. Biorąc więc pod uwagę cały kontekst, możemy więc stwierdzić, że ymaginem, które Jadwiga nosiła przy sobie, była właśnie figurka Matki Bożej wykonana z kości słoniowej.

\section{Podsumowanie}

Niewiele jest fragmentów Legendy maior mówiących o czci, jaką św. Jadwiga oddawała Matce Bożej. Jednak nawet na podstawie nielicznego materiału źródłowego można stwierdzić, że cześć wobec Maryi była w życiu księżnej śląskiej odzwierciedleniem ogólnej pobożności maryjnej średniowiecza. Na tę duchowość z pewnością wpłynęły trzy wielkie zakony, które ukonstytuowały się we wczesnym średniowieczu: benedyktyni, cystersi i franciszkanie. Szczególne dla czasów średniowiecza było fundowanie przez władców kościołów i klasztorów. Czyniła to także Jadwiga, fundując kościoły i ołtarze,

${ }^{70}$ Słownik łacińsko-polski, t. 2, s. 279.

${ }^{71}$ Por. J. Nowiński, Turris eburnea, Tabernaculum aureum, Templum Dei, Arca Foederis. Średniowieczne figury maryjne przechowujące Eucharystię, „Seminare” 12 (1996), s. 283-29o.

${ }_{72}$ Zob. D. Szczerba, Praktyczny leksykon modlitwy, Kraków 2008, s. 76.

${ }^{73}$ Pyxis to niewielkie naczynia o kształcie czworobocznym, które były przykryte dwuspadowym dachem, lub cylindryczne puszki o przykryciu zamocowanym na zawias w kształcie kopuły bądź stożka. Zob. J. Nowiński, Turris eburnea, Tabernaculum aureum, Templum Dei, Arca Foederis. Średniowieczne figury maryjne przechowujące Eucharystię, s. 283. 
a wśród nich również te poświęcone Matce Bożej, czego przykład mamy w klasztorze trzebnickim. Święta z Trzebnicy w swojej pobożności wobec Matki Chrystusa nie koncentrowała się jedynie na fundacjach kościołów. Przede wszystkim oddawała Maryi cześć, modląc się przez jej wstawiennictwo, czego przykład znajdujemy w historii opisanej w Legenda maior, wspominającej, jak jedna $\mathrm{z}$ współsióstr podglądała ją modlącą się przed ołtarzem Matki Bożej. W swoich modlitwach nie ograniczała się jedynie do powierzchowności i sentymentalizmu. Z pewnością przez modlitwę do Matki Bożej Jadwiga nawiązywała z nią głęboką relację, do tego stopnia, że potem wierni nazywali ją służebnicą Maryi ${ }^{74}$. Wymownym znakiem maryjnej pobożności św. Jadwigi było też noszenie przy sobie figurki Matki Bożej. Bardzo możliwe, że było to przedstawienie Maryi jako Matki Miłosierdzia, które zrodziło się właśnie w kręgu cysterskim. Bez wątpienia św. Jadwiga kształtowała swoje życie na wzór Maryi - Matki Miłosierdzia, pochylając się nad wszystkim potrzebującymi i ubogimi.

Reasumując, należy stwierdzić, że maryjna duchowość średniowiecza znajduje swe odzwierciedlenie w życiu i działalności św. Jadwigi Śląskiej, która z pewnością nadała jej osobisty rys.

\section{Bibliografia}

Andrzejuk A., Mistyka miłości Bożej w pismach św. Bernarda z Clairvaux, „Studia Philosophiae Christianae" 47 (2011) nr 2, s. 63-102.

Baran G. M., Nowak P., Święta Jadwiga Śląska - patronka dębickiego grodu, Dębica 2015.

Bartnik Cz. S., Matka Boża, Lublin 2012.

${ }^{74}$ Autor Legenda maior opisuje wydarzenie, które dotyczyło uzdrowienia z bólu głowy i zaćmy pani Bogusławy, żony pana Szymona, kasztelana gnieźnieńskiego. Cierpiała ona na ból głowy, który doprowadził aż do zaćmienia wzroku. Ślubowała ona pielgrzymkę i modlitwę u grobu św. Jadwigi. Modląc się przy grobie śląskiej księżnej, wypowiedziała modlitwę, w której nazywała św. Jadwigę służebnicą Maryi: „Pani moja, Najświętsza Maryjo, wysłuchaj mnie i racz polecić św. Jadwidze, Twojej służebnicy, aby mnie wybawiła od cierpień, a ty, św. Jadwigo, wspomóż mnie, twoją niegodną służebnicę" (Legenda świętej Jadwigi, s. 88-89). Po jej odmówieniu pani Bogusława została uwolniona od swoich cierpień związanych z bólem głowy i utratą wzroku. 
Bochnak W., Niewiasta mężna i czcigodna. Z życia i działalności św. Jadwigi Śląskiej, w: Bulla kanonizacyjna św. Jadwigi Śląskiej, wprowadzenie i przekł. S. Rosik, red. W. Bochenek, Legnica-Brzeg Dolny 2014, s. 7-46.

Borkowska M., Duchowość polskich klasztorów żeńskich w średniowieczu, „Saeculum Christianum" 3 (1996) nr 1, s. 111-124.

Chmielewski M., Walewander E., Benedyktyńska szkoła duchowości, w: Leksykon duchowości katolickiej, red. M. Chmielewski, Lublin-Kraków 2002, s. 74-77.

Daniluk M., Maryjność a maryjności. Różnorodność maryjnych aspektów duchowości zakonnej, „Summarium. Sprawozdania TN KUL” 20-21 (1991-92), s. 73-83. Dola K., Hedwig, w: Marienlexikon, Hrsg. R. Bäumer, L. Scheffczyk, Bd. 3, St. Ottilien 1991, s. 89.

Grenz B. A., Cysterska szkoła duchowości, w: Leksykon duchowości katolickiej, red. M. Chmielewski, Lublin-Kraków 2002, s. 150-154.

Heinz A., Uwielbienie Misteriów jako pierwotna intencja Różańca Świętego, „Jasna Góra” 1985 nr 10, s. 4-8.

Jackiewicz K., Kult Matki Bożej w zakonie cystersów, „Jasna Góra” 1986 nr 9, s. 25-29. Janiec Z., Kult Maryi w Polsce na przestrzeni dziejów. Zarys problematyki, Sandomierz 2013.

Kapera I., J. Kapera, Opactwa cysterskie w Polsce i ich wpływ na rozwój turystyki, „Peregrinus Cracoviensis” 25 (2014) nr 3, s. 79-90.

Kiełbasa A., Święta Jadwiga patronka dnia wyboru Jana Pawła II, Rzym-Trzebnica 1985 .

Kiełbasa A., Święta Jadwiga Śląska jako wychowawczyni własnych dzieci i swoich wnuków, Trzebnica 1994.

Klauza K., Franciszkańska reguła, w: Encyklopedia katolicka, red. Bieńkowski, P. Hemperek i in., t. 5, Lublin 1989, kol. 564-566.

Klauza K., M. Daniluk, Franciszkanie. Geneza i dzieje, w: Encyklopedia katolicka, red. Bieńkowski, P. Hemperek i in., t. 5, Lublin 1989, kol. 474-477.

Knapiński R., Od pokrowy do płaszcza opieki. Przeobrażenia motywu ikonograficznego Mater Misericordiae, „Studia Warmińskie” 39 (2002), s. 131-160.

Kostrzański H., Dziedzictwo białych mnichów, Szczyrzyc 1991.

Legenda świętej Jadwigi, przetł. A. Jochelson, M. W. Gogolewska, Wrocław 1993.

Lekan J., Pośredniczka w Chrystusie, „Salvatoris Mater” 4 (2002) nr 3, s. 86-112.

Lipiński H., Zasadnicze idee duchowości św. Franciszka i aktualność franciszkańskiej drogi, „Śląskie Studia Historyczno-Teologiczne” 10 (1977), s. 169-175.

Michalski M., Coitus albo consensus, czyli co stanowi o ważności małżeństwa. Relacja z pewnej dyskusji z XI-XIII wieku, w: Nihil superfluum esse. Prace z dziejów 
średniowiecza ofiarowane Profesor Jadwidze Krzyżaniakowej, red. J. Strzelczyk, J. Dobosz, współpr. Z. Górczak i in., Poznań 200o, s. 163-164.

Michalski M., Vita perfecta. Wzorce świętości w żywotach trzynastowiecznych księżnych polskich, Poznań 2001.

Monumenta Poloniae Historica. Pomniki dziejowe Polski, wyd. A. Semkowicz, t. 4, Lwów 1884.

Nowak J., Maryja w liturgii i pobożności Kościoła, Poznań 2009.

Nowiński J., Turris eburnea, Tabernaculum aureum, Templum Dei, Arca Foederis: średniowieczne figury maryjne przechowujące Eucharystię, „Seminare” 12 (1996), s. 283-290.

Rybicki A., Maryjna duchowość, w: Leksykon duchowości katolickiej, red. M. Chmielewski, Lublin-Kraków 2002, s. 493-496.

Schmitz Ph., Renner F., Benediktiner, w: Marienlexikon, Hrsg. R. Bäumer, L. Scheffczyk, Bd. 1, St. Ottilien 1988, s. 425-430.

Słotwiński T., Trójca Święta a Maryja u św. Franciszka z Asyżu i św. Antoniego $z$ Padwy, „Salvatoris Mater” 2 (2000) nr 3, s. 268-29o.

Straszewicz M., Maryja. Kult pozaliturgiczny, w: Encyklopedia katolicka, red. E. Ziemianin, t. 12, Lublin 2008, kol. 37-39.

Sutowicz A., Maryja $w$ duchowości ślaskich klarysek i benedyktynek $w$ okresie średniowiecza, „Perspectiva. Lednickie Studia Teologiczno-Historyczne” 10 (2011) nr 1, s. 209-225.

Szczerba D., Praktyczny leksykon modlitwy, Kraków 2008.

Św. Benedykt z Nursji, Reguła. Żywot. Komentarz, Tyniec 1979.

Tabor D., Psatterz trzebnicki. Między egzegeza a duchowościa, w: Cysterki w dziejach $i$ kulturze ziem polskich, dawnej Rzeczypospolitej i Europy Środkowej. Materiały z siódmej Międzynarodowej Konferencji Cystersologów odbytej z okazji 800. rocznicy fundacji opactwa cysterek $w$ Trzebnicy; Trzebnica 18-21 września 2002 r., red. A. M. Wyrwa, A. Kiełbasa, J. Swastek, Poznań 2004, s. 121-129.

Zachara M., Maryja. Kult liturgiczny, w: Encyklopedia katolicka, red. E. Ziemianin, t. 12, Lublin 2008, kol. 33-37.

Zientara B., Henryk Brodaty i jego czasy, Warszawa 1975.

Zientara B., Świetność i upadek możnego rodu, czyli dramatyczne dzieje książąt Meranii, „Mówią Wieki” 1973 nr 3, s. 5-8. 


\section{Streszczenie}

Na duchowość św. Jadwigi - księżnej śląskiej wpływ wywarły trzy wielkie zakony wczesnego średniowiecza: benedyktyni, cystersi i franciszkanie. Jadwiga w młodości została wychowana w benedyktyńskim klasztorze w Kitzingen. Wraz z mężem ufundowała cysterski klasztor w Trzebnicy, według reguły którego żyła po śmierci męża, a jej spowiednikiem był zakonnik franciszkański. Maryjna duchowość tych trzech zakonów znalazła odzwierciedlenie w kulcie Matki Bożej w życiu św. Jadwigi.

Księżna śląska czciła Matkę Bożą poprzez modlitwę do niej, fundowanie kościołów i ołtarzy ku jej czci. W sposób szczególny oddawała Maryi cześć, nosząc przy sobie jej figurkę bądź też obraz. Tekst łaciński Legenda maior nie wskazuje jednoznacznie, czy była to figurka. Jednak analiza tego tekstu i zwyczajów, które panowały we wczesnym średniowieczu, pozwala na stwierdzenie, że była to figurka Matki Bożej.

\section{Słowa kluczowe}

Matka Boża, kult Matki Bożej, figurka Matki Bożej, św. Jadwiga Śląska, średniowiecze

\section{Summary}

\section{St. Mary's Piety in the Life of St. Hedwig of Silesia Against the Background of the Then Era}

The spiritual life of Saint Hedwig was strongly influenced by three great monastic orders of the Early Middle Ages: Benedictines, Cistercians and Franciscans. As a young girl she received her education at Benedictine Abbey of Kitzingen. Together with her husband she established a Cistercian convent in Trzebnica according to which religious rules she lived after her husband's death. She also had a Franciscan monk as her confessor.

Marian spirituality of these three convents had a significant influence upon the veneration of Virgin Mary in the life of Saint Hedwig of Silesia's.

Saint Hedwig worshiped Virgin Mary by prayer and pious acts such as donations of churches and altars devoted to the Blessed Virgin. Moreover, she constantly carried a picture or a statue of Virgin Mary with her. Although it is not clearly stated in the Latin text of Legnda maior whether it was a statue, however the analysis 
of the text and Early Middle Ages mores and customs allow to assume that it was the statue of Virgin Mary.

\section{Keywords}

Mother of God, worship of Our Lady, figurine of Our Lady, St. Hedwig of Silesia, Middle Ages 